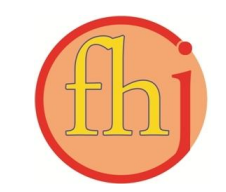

Faletehan Health Journal, 6 (1) (2019) 1-10

www. journal.Ippm-stikesfa.ac.id/ojs/index.php/FHJ

ISSN 2088-673X | e-ISSN 2597-8667

\title{
Faktor-Faktor Yang Berhubungan Dengan Kegemukan Pada Balita di Kelurahan Warnasari Kecamatan Citangkil Kota Cilegon
}

\author{
Sari Suriani $1^{*}$ \\ ${ }^{1}$ Sekolah Tinggi IImu Kesehatan Faletehan Serang, Indonesia \\ *Corresponding Author: riesarie28@yahoo.com
}

\begin{abstract}
Abstrak
Status gizi lebih merupakan kondisi dimana berat badan melebihi standar berat badan normal. Gizi lebih dapat terjadi pada semua lapisan umur, dari mulai bayi, balita, anak-anak, orang dewasa, dan lansia. Persatuan ahli gizi rumah sakit Cipto Mangun Kusumo (RSCM), mengatakan gizi lebih yang dapat menyebabkan kegemukan pada usia balita, kegemukkan berpotensi menyebabkan terjadinya peningkatan resiko penyakit degeneratif, gangguan saluran pernafasan, masalah jantung serta dapat beresiko terjadinya diabetes. Penelitian ini bertujuan untuk mengetahui hubungan kegemukkan pada balita di Kelurahan Warnasari Kecamatan Citangkil Kota Cilegon. Sampel pada penelitian ini adalah balita yang berusia 24-59 bulan, diperoleh sebanyak 94 balita. Hasil penelitian ini menunjukan terdapat 18 balita atau $19,1 \%$ balita yang termasuk dalam kategori gemuk, terdapat $60,6 \%$ balita yang berjenis kelamin laki-laki, berat badan lahir beresiko terdapat $16,0 \%$ balita, dan $13,8 \%$ ibu balita yang bekerja, $76,6 \%$ pendidikan ibu balita yang memiliki pendidikan tinggi, dan $75,5 \%$ keluarga balita yang memiliki jumlah keluarga $<4$ atau keluarga kecil. Terdapat hubungan antara jenis kelamin (pv: 0,003), Berat badan lahir (pv: 0,00), pekerjaan ibu (pv:0,00) dengan kegemukan pada anak balita. Tidak ada hubungan antara pendidikan dan jumlah anggota keluarga dengan kegemukan pada balita. Disarankan agar Dinas Kesehatan mengadakan upaya untuk mencegah kegemukan pada balita melalui monitoring dan evaluasi terhadap kegemukan Balita.
\end{abstract}

Kata Kunci: Balita, Berat Badan Lahir, kegemukan

\begin{abstract}
M ore nutritional status is a condition where body weight exceeds the normal weight standard. M ore nutrition can occur at all ages, from babies, toddlers, children, adults and the elderly. Nutritionists association of Cipto Mangun Kusumo Hospital (RSCM),said that over nutrition can cause obesity at the age of the toddler, fatigue can potentially cause an increased risk of degenerative diseases, respiratory tract disorders, heart problems and can be at risk of developing diabetes. This study aims to determine the relationship of fatigue in toddlers in Warnasari Village, Citangkil Subdistrict, Cilegon City. The sample in this study is toddlers aged 24-59 months, obtained as many as 94 toddlers. The results of this study showed that there were 18 children under five or $19.1 \%$ of children under five in the obese category, there were $60.6 \%$ of children under five who were male, birth weight at risk there were $16.0 \%$ of children under five, and $13.8 \%$ of children under five who works, $76.6 \%$ of education for under-five mothers who have higher education, and $75.5 \%$ of under-five families who have a family of $<4$ or a small family. There is a relationship between sex (pv: 0.003 ), birth weight (pv: 0.00), maternal work (pv: 0.00) with obesity in children under five. There is no relationship between education and the number of family members with obesity in children under five. It was suggested that the Health Service should make an effort to prevent obesity in children under five through monitoring and evaluating obesity.
\end{abstract}

Keywords: Toddler, Birth Weight, obesity 


\section{Pendahuluan}

Status gizi lebih merupakan kondisi dimana berat badan melebihi standar berat badan normal. Gizi lebih dapat terjadi pada semua lapisan umur, darimulai bayi, balita, anak-anak, orang dewasa, dan lansia. Persatuan ahli gizi. Rumah Sakit Cipto Mangun Kusumo (RSCM), mengatakan gizi lebih yang dapatmenyebabkan kegemukan dibagi dua yaitu berat badan overweight yang berarti berat badan lebih dari 10-20\% dari berat badan ideal, dan obesitas yaitukondisi tubuh memiliki berat badan lebih $20 \%$ berat badan ideal (Rimbawan, 2004).

Berdasarkan data Riset Kesehatan Dasar (Riskesdas, 2010) prevalensi kegemukan di kalangan balita di Indonesia adalah 14,0\% dimana lebih tinggi dari jumlah balita yang sangat kurus dan kurus yakni $6 \%$ dan $7,3 \%$. Berdasarkan kelompok umur prevalensi kegemukan pada usia 24-35 bulan sebesar $13,1 \%$ dan pada usia $36-47$ bulan serta $48-59$ bulan masing-masing $12,1 \%$ dan $12,0 \%$. Sementara hasil Riskesdas 2007 menunjukan prevalensi kegemukandi Indonesia sebesar $12,2 \%$ dan pada kelompok umur 24-35 bulan prevalensinya sebesar $10,9 \%$ dan pada kelompok 36-47 bulan serta 48-59 bulan masing-masing $11,2 \%$ dan $10.7 \%$.Di Provinsi Banten prevalensi kegemukan pada balita 0-59 bulan berdasarkan data Riskesdas tahun 2010 adalah $11,7 \%$ mengalami penurunan yaitu dari 15,6\% pada tahun 2007 (Riskesdas, 2010) Sedangkan Data Riskesdas 2013 prevalensi bayi dengan berat badan lahir rendah (BBLR) berkurang dari $11,1 \%$ dari tahun 2010 menjadi 10,2 \% pada tahun 2013 (Kemenkes, Hasil Riset Kesehatan Dasar (RISKESDAS 2013), 2013)

Berat masalah gizi Kota/Kabupaten provinsi Banten berdasarkan hasil PSG tahun 2017 di Kota Cilegon hasil Pemantauan Status Gizi kegemukan pada anak balita sebesar 3,5\% dari jumlah seluruh Balita. Sedangkan berdasarkan data Pemantauan Status Gizi pada bulan Penimbangan dibulan Februari Tahun 2018, persentase kegemukan pada anak balita di Kota Cilegon sebesar 1,3\%, dan jumlah paling banyak dalam kategori daerah perkotaan adalah di Kelurahan Warnasari Kecamatan Citangkil yaitu 0,9\% dari jumlah penduduk Balita yang ditimbang.

Angka prevalensi kegemukan yang sudah ada, menjadi peringatan bagi pemerintah dan masyarakat, bahwa kegemukan merupakan ancaman serius bagi masyarakat Indonesia. Sasaran pemerintah Indonesia dalam strategi operational dalam menanggulangi masalah kegemukan yaitu menahan laju peningkatan prevalensi kegemukan dan obesitas pada kelompok balita, anak usia sekolah, remaja dan dewasa dari $1 \%$ menjadi $0,5 \%$ pertahun (Kemenkes, 2012).

Menurut Thorpe, kegemukan yang terjadi selama masa kanak-kanak, memiliki konsekuensimedis jangka pendek, meliputi efek yang merugikan terhadap pertumbuhan, dankonsekuensi medis jangka panjang meliputi risiko yang lebih besar untukterkena hipertensi, diabetes, penyakit kardiovaskuler, dan penyakit degeneratif lainnya pada masa dewasa (Musadat, 2010). Kegemukan pada masa anak-anak juga menimbulkan konsekuensi psikososial jangka pendek dan jangka panjang sepertipenurunan kepercayaan diri, gangguan makan, dankesehatan yang lebih rendah hubungannya dengan kualitas hidup. Kondisi kegemukan pada usia dini akan dibawa sampai dewasa, yang berdampak terhadap peningkatan resiko penyakit degeneratif. Meningkatnya status sosial ekonomi masyarakat saat ini, ditambah lagi dengan gaya hidup yang kurang baik, seperti banyak tawaran makanan siap saji, dan kurangnya aktifitas fisik cenderung meningkatkan kejadian gizi lebih.

Hasil penelitian epidemiologi bahwa gizi lebih atau kegemukan memiliki resiko relatif sebesar 5,9 kali untuk hipertensi dan 2,9 kali untuk diabetes mellitus, dibandingkan dengan kelompok gizi normal. Hal ini membuktikan bahwa terdapat hubungan erat antara kegemukan dan faktor resiko penyakit kardiovaskuler seperti diabetes mellitus tipe II, 
Faletehan Health Journal, 6 (1) (2019) 1-10 www. journal.Ippm-stikesfa.ac.id/ojs/index.php/FHI ISSN 2088-673X | 2597-8667

dislipidemia dan hipertensi. Bertambahnya populasi kegemukan dan obesitas dengan sendirinya akan meningkatkan angka kesakitan dan kematian penyakit kardiovaskuler (Hariadi \& Ali, 2005).

Hasil penelitian di Indonesia menyatakan hubungan yang bermakna antara variabel berat badan lahir, pekerjaan ibu dan pengeluaran keluarga dengan kegemukan dan obesitas (Fitriarni, 2012). Sedangkan hasil penelitian di Provinsi Sumatera Selatan, faktor yang mempengaruhi kegemukan adalah jenis kelamin, umur, genetik orang tua (IMT Ayah), aktifitas fisik, kebiasaan makan buah, kebiasaan makan makanan berlemak, konsumsi energi, dan konsumsi protein (Musadat, 2010).

Penelitian serupa terhadap anak SD di Jakarta Selatan, menyimpulkan bahwa ada hubungan yang bermakna antara jenis kelamin dengan kejadianobesitas dan tidak ada hubungan yang bermakna antara usia, pendidikan Ibu, status pekerjaan Ibu, frekuensi konsumsi makanan jajanan, frekuensi konsumsi makanan cepat saji, waktu tidur, menonton TV dan main games, kebiasaan olahraga dan keterpaparan media (Rahmawati, 2009). Berdasarkan karakteristik permasalahan kegemukan dan obesitas sangat dominan pada kelompok penduduk yang tinggal di perkotaan dimana status ekonomi yang lebih baik dan tingkat pendidikan tinggi (Kemenkes, 2012).

Tujuan penelitian ini adalah untuk mengetahui Faktor-Faktor Yang Berhubungan Dengan Kegemukan Pada Balita Di Kelurahan Warnasari Kecamatan Citangkil Kota Cilegon Tahun 2018.

\section{Metode Penelitian}

Penelitian ini merupakan jenis penelitian Observasional dengan menggunakan metode observasi, wawancara dan pengukuran antropometri. Adapun berdasarkan waktunya jenis penelitian ini bersifat cross sectional (Notoatmodjo, 2005). Penelitian dilakukan di Kelurahan Warnasari Kecamatan Citangkil Kecamatan Warnasari Kota Cilegon.
Penelitian ini dilakukan pada bulan Mei - Juli 2018. Populasi dalam penelitian ini adalah seluruh balita yang tercatat di Kelurahan Warnasari sejumlah 1.607 jiwa.

Dalam pengambilan sampel dilakukan secara Accidental sampling dari balita yang datang dan ditimbang di posyandu Kelurahan Warnasari Kecamatan Citangkil dengan kriteria inklusi; Balita termasuk warga Kelurahan Warnasari, berusia 24-59 Bulan, Masih memiliki orang tua (kandung maupun angkat).Alat pengumpulan data berupa kuesioner, timbangan injak, dan microtoice. Cara pengumpulan data melalui wawancara dan pengukuran langsung. Uji statistik untuk mengetahui hubungan antara variabel independen dengan variabel independen menggunakan tingkat kepercayaan 95\% (alpha $5 \%)$.

\section{Hasil dan Pembahasan}

Berdasarkan hasil penelitian, gambaran kegemukan dikelompokan menjadi gemuk dan tidak gemuk dimana status gemuk merupakan hasil dari analisa penentuan status gizi menurut $\mathrm{BB} / \mathrm{TB}$ berdasarkan tabel antropometri yang mengacu pada standar WHO tahun 2005. Proporsi kegemukan pada anak balita sebesar $19,1 \%$, sedangkan sisanya tidak mengalami kegemukan yaitu sebesar $80,9 \%$.

Tingginya prevalensi kegemukan mengindikasikan bahwa pertumbuhan pada anak terkait dengan faktor jangka panjang. Tingkat sosial ekonomi tinggi dan status lingkungan yang baik ditemukan menjadi protektif terhadap kegemukan. Fenomena kegemukan merupakan ancaman yang serius karena terjadi di berbagai kelompok usia, strata ekonomi, tingkat pendidikan, desa maupun kota. Peningkatan pendapatan pada kelompok masyarakat terutama di perkotaan menyebabkan perubahan gaya hidup, terutama dalam hal pola makan. Saat ini pola makan masyarakat bergeser dari pola makan yang tadinya tinggi karbohidrat kompleks, tinggi serat, dan rendah lemak berubah ke pola makan yang tinggi karbohidrat sederhana, rendah serat, dan tinggi lemak, sehingga 
menggeser mutu makanan kearah tidak seimbang.

Jenis kelamin merupakan faktor internal yang menentukan kebutuhan gizi, dan akan berpengaruh terhadap status gizi, sehingga terdapat hubungan antara dan jenis kelamin dengan status gizi. Penelitian ini diikuti $60,6 \%$ balita laki-laki dan $39,4 \%$ balita perempuan. Sebaran ini tidak jauh berbeda jika dilihat berdasarkan Sensus penduduk pada tahun 2010 wilayah kecamatan Cilegon proporsi anak balita di usia 0-59 bulan adalah sebesar $51,95 \%$ memiliki jenis kelamin laki-laki dan sebesar 48,05\% memiliki jenis kelamin perempuan.

Laki-laki dan perempuan mempunyai kecenderungan yang berbeda untuk berstatus gizi lebih. Anak laki-laki mempunyai kecenderungan lebih untuk menjadi gizi lebih (overweight) dibandingkan dengan anak perempuan. Berdasarkan data National Health and Nutrition Examination Survey, terjadi peningkatan prevalensi gizi lebih pada anak laki-laki dari $14 \%$ sampai $18 \%$, sementara pada anak perempuan $13,8 \%$ sampai $16 \%$. Penelitian Dupuy membuktikan bahwa lakilaki lebih berpotensi untuk mengalami status gizi lebih dibandingkan dengan perempuan (Dupuy, Vignes, Godeau, \& Ahluwalia, 2011).

Masalah kegemukan dapat berawal dari masa bayi dimana berat badan lahir juga mencerminkan kualitas pemeliharaan kesehatan mencakup pelayanan kesehatan yang diterima oleh ibu selama kehamilannya. Kategori berat badan lahir dikategorikan menjadi 2 yaitu kategori beresiko jika berat badan lahir <2500 gram atau >4000 gram, sedangkan kategori tidak beresiko jika berat badan lahir 2500-4000 gram.

Dari penelitian ini diperoleh, sebanyak $16,0 \%$ balita yang memiliki berat badan lahir kategori beresiko dan $84 \%$ tidak beresiko. Rata-rata berat badan lahir adalah 3115,2 gram dengan standar deviasi $\pm 467,55$ gram. Berat badan lahir terendah adalah 2150 gram dan tertinggi adalah 4300 gram.

Gambaran karakteristik anak balita di Kelurahan Warnasari jika dianalisis lebih lanjut proporsi anak balita yang memiliki jenis kelamin laki-laki yang berusia 24-59 bulan dengan riwayat berat badan lahir dalam kategori beresiko adalah sebesar $16,0 \%$ dari jumlah keseluruhan anak balita yang memiliki berat lahir beresiko. Perlu diketahui resiko kegemukan terjadi pada kelompok anak balita yang memiliki jenis kelamin laki-laki, pada kelompok anak balita berusia 24-59 bulan, dan pada kelompok anak balita dengan riwayat BBLR.

Kecenderungan berat lahir yang lebih dari 4000 gram untuk mengalami kegemukkan dikarenakan terjadi peningkatan massa jaringan tubuh. Di satu sisi, kecenderungan berat lahir yang kurang dari 2500 gram untuk berstatus gizi lebih karena terjadi peningkatan massa lemak dalam tubuh (Lopez, Mathers, Ezzati, Jamison, \& Murray, 2006).

Tabel 1. Distribusi frekuensi responden berdasarkan status kegemukan, jenis kelamin, berat badan lahir, pendidikan ibu, pekerjaan ibu dan jumlah anggota keluarga

\begin{tabular}{lcc}
\hline \multicolumn{1}{c}{ Variabel } & F & \% \\
\hline Status Kegemukan & & \\
$\quad$ Gemuk & 18 & 19,1 \\
$\quad$ Tidak Gemuk & 76 & 80,9 \\
\hline Jenis Kelamin & & \\
$\quad$ Laki-laki & 57 & 60,6 \\
$\quad$ Perempuan & 37 & 39,4 \\
\hline Berat Badan Lahir & & \\
$\quad$ Beresiko & 15 & 16,0 \\
$\quad$ Tidak beresiko & 79 & 84,0 \\
\hline Pendidikan Ibu & & \\
$\quad$ Rendah ( $\leq$ SMP) & 22 & 23,4 \\
$\quad$ Tinggi (> SMA) & 72 & 76,6 \\
\hline Pekerjaan Ibu & & \\
$\quad$ Bekerja & 14 & 14,9 \\
$\quad$ Tidak bekerja & 80 & 85,1 \\
\hline Jumlah Anggota & & \\
Keluarga & & \\
Besar ( $\geq 4$ orang) & 71 & 75,5 \\
$\quad$ Kecil (<4 orang) & 23 & 24,5 \\
\hline Jumlah & 94 & 100 \\
\hline
\end{tabular}

Sumber : Data Primer, 2018 
Faletehan Health Journal, 6 (1) (2019) 1-10 www. journal.Ippm-stikesfa.ac.id/ojs/index.php/FHJ ISSN 2088-673X | 2597-8667

Berdasarkan hasil penelitian, sebagian besar ibu balita memiliki jenjang pendidikan yang tinggi (>SMP) yaitu $76,6 \%$, sedangkan $25,5 \%$ ibu balita memiliki pendidikan rendah ( $\leq$ SMP). Secara biologis ibu adalah sumber hidup anak. Tingkat pendidikan ibu banyak menentukan sikap dan menghadapi berbagai masalah, misal memintakan vaksinasi untuk anaknya, memberikan oralit waktu diare, atau kesediaan menjadi peserta KB. Anak-anak dari ibu yang mempunyai latar pendidikan lebih tinggi akan mendapat kesempatan hidup serta tumbuh lebih baik. Keterbukaan mereka untuk menerima perubahan atau hal baru guna pemeliharaan kesehatan anak maupun salah satu penjelasannya.

Status pekerjaan ibu dikelompokkan menjadi dua yaitu bekerja apabila ibu mempunyai pekerjaan yang menghasilkan pendapatan, dan tidak bekerja apabila ibu tidak bekerja atau tidak memiliki pendapatan yang tetap hanya mengurus rumah tangga saja. Dari hasil penelitian ini dan sebelumnya menunjukkan bahwa sebagian besar ibu pada anak balita adalah seorang ibu rumah tangga. Sehingga pengetahuan ibu tentang makanan tinggi kalori masih rendah, ibu membiarkan anaknya untuk mengkonsumsi makanan siap saji yang sedikit zat gizi mengingat proses persiapan yang sebagian besar adalah digoreng (Anderson, 2002).

Jumlah anggota keluarga diteliti karena besar keluarga bila bertambah maka pangan untuk setiap anak berkurang dan banyak orang tua tidak menyadari bahwa anak-anak yang sangat muda memerlukan pangan relatif lebih banyak daripada anak-anak yang lebih tua. Dengan demikian anak-anak yang muda mungkin tidak diberi cukup makan. Berdasarkan penelitian diatas, proporsi jumlah anggota keluarga $\geq 4$ orang adalah sebesar $24,5 \%$, sedangkan $75,5 \%$ beranggota kurang atau sama dengan 4 orang (keluarga kecil $(<4$ orang).

Hasil penelitian secara statistik menunjukkan ada hubungan bermakna antara jenis kelamin dengan kegemukan pada anak balita. Hasil ini sesuai dengan hasil penelitian sebelumnya yang menunjukan ada hubungan antara jenis kelamin dengan kegemukan (Fitriarni, 2012). Namun berbeda dengan hasil penelitian yang menunjukan bahwa tidak ada hubungan yang bermakna antara jenis kelamin dengan kegemukan atau obesitas (Musadat, 2010). Jenis kelamin membedakan kebutuhan zat gizi seseorang. Karena luas permukaan dan otot tubuhnya, laki-laki lebih banyak membutuhkan energi dibandingkan perempuan.

Hasil uji statistik dapat disimpulkan adanya hubungan antara jenis kelamin dengan kegemukan. Hasil penelitian ini proporsi kejadian kegemukan pada anak balita laki-laki yaitu 29,8\% lebih tinggi jika dibandingkan pada anak balita perempuan yang mengalami kegemukan yaitu sebanyak 2,7\%. Hasil penelitian lain juga menyebutkan bahwa anak laki-laki lebih banyak yang gemuk dibandingkan anak perempuan (Musadat, 2010) (Fitriarni, 2012).

Kecenderungan kegemukan terjadi pada anak laki-laki dibandingkan perempuan dapat disebabkan karena perbedaan asupan makanan. Anak laki-laki mengkonsumsi energi dan protein yang lebih besar dibandingkan dengan anak perempuan, nafsu makanpada anak laki-laki sangat tinggi sehingga tidak ada kesulitan untuk memenuhi kebutuhan makanannya. Anak laki-laki mempunyai nafsu makan yang besar sehingga mengkonsumsi makanan yang lebih banyak terutama makanan yang mengandung energi lebih tinggi dibandingkan anak perempuan.

Berdasarkan penelitian Fitriarni, analisis lebih lanjutan antara jenis kelamin dengan konsumsi Air Susu Ibu (ASI) eksklusif didapatkan hasil bahwa anak laki-laki yang mengonsumsi ASI eksklusif lebih sedikit dibandingkan dengan anak perempuan (Fitriarni, 2012). Kita ketahui bahwa ASI eksklusif mempunyai efek protektif terhadap kegemukan sehingga anak laki-laki dalam penelitian lebih banyak yang gemuk dibandingkan dengan anak perempuan. 
Berdasarkan hasil analisis hubungan antara berat badan lahir dengan kegemukan diperoleh kejadian kegemukan pada anak balitayang memiliki berat lahir beresiko $(<2500$ gr dan $>4000 \mathrm{gr})$ yaitu sebesar $80,0 \%$, sedangkan pada anak balita yang memiliki berat lahir tidak beresiko (2500-4000 gr) yang mengalami kegemukan yaitu sebesar 7,6\%.

Hasil uji statistik dapat disimpulkan bahwa tidak adanya hubungan yang signifikan antara berat badan lahir dengan kegemukan pada anak balita. Penelitian ini sesuai dengan hasildaripenelitian yang menyebutkan tidak menemukan hubungan yang bermakna antaraberat lahir dengan kegemukan pada anak usia 24-59 bulan (Kusumaningrum, 2011). Namun hasil yang sesuai di dapatkan pada penelitian lain yang menunjukkan hubungan yang bermakna antara beratlahir dengan kegemukan (Fitriarni, 2012).Anak yang gemuk lebih banyak yang memiliki beratlahir lebih ( $\geq 4000$ gr).
Perlu diketahui bahwa kegemukan dapat berawal dari bayi. Banyak penelitian yang menunjukkan bahwa anak balita yang dilahirkan dengan Bayi Berat Lahir Rendah (BBLR) mempunyai resiko yang lebih besar untuk menjadi kegemukan di masa mendatang. Hal ini karena BBLR mempunyaimassa tubuh tanpa lemak (lean body mass) yang lebih rendah daripada bayi yang lahir dengan berat lahir cukup. Seperti halnya pernyataan AlQaoud dan Prakash yang menyebutkan bahwa anak-anak yang lahir dengan berat lahir besar (4000 gr) memiliki risiko 2,5 kali terkena obesitas/ kegemukan dibandingkan dengan berat lahir normal, sedangkan untuk bayi dengan berat badan lahir rendah memiliki resiko terkena kegemukan dikarenakan kesalahan penanganan bayi yaitu bayi diberi asupan protein yang tinggi untuk mengejar ketertinggalan pertumbuhannya dengan anakanak yang lahir dengan berat badan normal (Al-Qaoud \& Prakash, 2009).

Tabel 2. Hubungan jenis kelamin, berat badan lahir, pendidikan ibu, pekerjaan ibu dan jumlah anggota keluarga terhadap kegemukan pada anak

\begin{tabular}{|c|c|c|c|c|c|c|c|c|}
\hline \multirow{3}{*}{ Variabel } & \multicolumn{4}{|c|}{ Status Kegemukan } & \multicolumn{2}{|c|}{ Jumlah } & \multirow{3}{*}{ Pvalue } & \multirow{3}{*}{$\mathbf{O R}$} \\
\hline & \multicolumn{2}{|c|}{ Gemuk } & \multicolumn{2}{|c|}{ Tidak Gemuk } & \multirow{2}{*}{$\mathbf{n}$} & \multirow{2}{*}{$\%$} & & \\
\hline & $\mathbf{N}$ & $\%$ & $\mathbf{N}$ & $\%$ & & & & \\
\hline \multicolumn{9}{|l|}{ Jenis Kelamin } \\
\hline Laki-laki & 17 & 29,8 & 40 & 70,2 & 57 & 100 & 0,003 & 15,300 \\
\hline Perempuan & 1 & 2,7 & 36 & 97,3 & 37 & 100 & & \\
\hline \multicolumn{9}{|l|}{ Berat Badan Lahir } \\
\hline Berisiko & 12 & 80 & 3 & 20 & 15 & 100 & 0,000 & 9,692 \\
\hline Tidak Berisiko & 6 & 7,6 & 73 & 92,4 & 79 & 100 & & \\
\hline \multicolumn{9}{|l|}{ Pendidikan Ibu } \\
\hline Rendah $(\leq \mathrm{SMP})$ & 2 & 9,1 & 20 & 90,9 & 22 & 100 & 0,225 & \\
\hline Tinggi (> SMP) & 16 & 22,2 & 56 & 77,8 & 72 & 100 & & \\
\hline \multicolumn{9}{|l|}{ Pekerjaan Ibu } \\
\hline Bekerja & 11 & 78,6 & 3 & 21,4 & 14 & 100 & 0,000 & 38,238 \\
\hline Tidak Bekerja & 7 & 8,8 & 73 & 91,3 & 80 & 100 & & \\
\hline \multicolumn{9}{|l|}{ Jumlah Anggota } \\
\hline \multicolumn{9}{|l|}{ Keluarga } \\
\hline Besar ( $\geq 4$ orang) & 2 & 8,7 & 21 & 91,3 & 23 & 100 & 0,246 & \\
\hline Kecil ( $<4$ orang) & 16 & 22,5 & 55 & 77,5 & 71 & 100 & & \\
\hline
\end{tabular}

Sumber : Data Primer, 2018 
Faletehan Health Journal, 6 (1) (2019) 1-10

www. journal.Ippm-stikesfa.ac.id/ojs/index.php/FHJ

ISSN 2088-673X | 2597-8667

Tinggi rendahnya tingkat pendidikan ibu erat kaitannya dengan tingkat pengetahuan terhadap perawatan kesehatan, proses kehamilan dan pasca persalinan, serta kesadaran terhadap kesehatan dan gizi anakanak dan keluarganya. Tingkat pendidikan turut pula menentukan mudah tidaknya seseorang menyerap dan memahami pengetahuan gizi yang mereka peroleh. Pendidikan diperlukan agar seseorang lebih tanggap terhadap adanya masalah gizi didalam keluarga dan bisa mengambil tindakan secepatnya (Suhardjo, 2003).

Hasil analisis hubungan antara pendidikan ibu dengan kegemukan pada anak balita diperoleh proporsi kejadian kegemukan pada anak balita dengan pendidikan ibu dalam kategori rendah yaitu sebesar $9,1 \%$, sedangkan untuk pandidikan ibu kategori tinggi yang memiliki anak balita mengalami kegemukan yaitu sebesar $22,2 \%$.

Hasil uji statistik dapat disimpulkan bahwa tidak adanya hubungan yang signifikan antarapendidikan ibu dengan kegemukan pada anak balita. Hasil penelitian sesuai dengan hasil penelitian lain yang menyatakan bahwa tidak ada hubungan antara pendidikan orang tua dengan kegemukan (Musadat, 2010) (Rahmawati, 2009). Namun hasil penelitian ini berbeda dengan hasil penelitian yang menemukan adanya hubungan yang bermakna antara tingkat pendidikan orang tua dengan kejadian obesitas (Nugroho, 1999).

Tidak ditemukannya hubungan yang bermakna antara pendidikan orang tua dengan kejadian kegemukan diduga karena faktor pendidikan bukan merupakan faktor langsung yang mempengaruhi status gizi, tetapi pendidikan sangat berpengaruh pada tingkat pengetahuan. Pengetahuan kesehatan dan gizi merupakan faktor yang sangat mempengaruhi pola konsumsi makan.

Di zaman modern saat ini banyak wanita yang bekerja baik itu termasuk kedalam pekerjaan terampil maupun yang tidak terampil. Kondisi saat ini, dalam satu keluarga ibu yang bekerja merupakan suatu kebutuhan untuk menopang perekonomian keluarga. Banyak alasan yang menyebabkan ibu harus bekerja diantaranya untuk kebutuhan hidup sehari-hari, untuk biaya sekolah anak, dll.

Tempat kerja pun sekarang pada umumnya lebih memilih wanita yang dipekerjakan di kantornya dikarenakan wanita memiliki sifat yang lebih sabar,teliti dan loyal pada pekerjaannya. Hal-hal tersebut membuat anak-anak dalam keluarga tersebut diasuh atau diawasi oleh asisten rumah tangga, saudara atau kakek dan neneknya.

Pengasuhan anak-anak tidaklah mudah, apalagi anak-anak tersebut masih dalam kategori di bawah usia tiga tahun. Usia di bawah tiga tahun merupakan usiayang rawan karena masih dalam tahap perkembangan yang sangat pesat. Cukup sulit untuk seorang ibu menyerahkan pengasuhan anak-anaknya kepada seorang asisten rumah tangga, karena tidak hanya mengasuh saja tugasnya namun juga termasuk ke dalam penyiapan, pengolahan dan pemberian makanan terhadapanak. Untuk penyiapan dan pengolahan makanan anak-anak, ibu yang bekerja menggunakan waktunya di pagi hari, tetapi terkadang untuk penyiapan dan pengolahan makanan ibu yang bekerja juga tidak sempat melakukannya sehinggasemua diserahkan kepada asistennya.

Berdasarkan hasil analisis hubungan antara pekerjaan ibu dengan kegemukan pada anak balita diperoleh kejadian kegemukan pada anak balita dengan ibu yang memiliki jenis pekerjaan karyawan swasta yaitu sebesar $84,6 \%$,kejadian kegemukan pada anak balita dengan ibu yang memiliki jenis pekerjaan buruh harian yaitu sebesar $0,0 \%$, sedangkan untuk ibu yang tidak bekerja dan memiliki anak balita mengalami kegemukan yaitu sebesar 8,8\%. Dari data diatas secara presentase bahwa anak balita dengan ibu bekerja lebih tinggi dibandingkan dengan anak balita dengan ibu yang tidak bekerja.

Hasil uji statistik dapat disimpulkan bahwa tidak adanya hubungan yang signifikan antara pekerjaan ibu dengan kegemukan pada 
anak balita. Hasil penelitian ini sesuai dengan penelitian yang menyatakan bahwa tidak ditemukan hubungan antara status pekerjaan ibu terhadap kegemukan (Rahmawati, 2009). Menurut Shils Maurice E. menyatakan ibu bekerja ternyata dapat memperbaiki status gizi anak sebagai akibat meningkatnya penghasilan terutamasekali bila ibu yang mengontrol penghasilan keluarga (Rahmawati, 2009). Selain itu wanita juga lebihbanyak menggunakan penghasilannya untuk pemberian makan pada anak-anaknya. Begitu juga penelitian ini sesuai dengan yang menunjukkan tidak adanyahubungan antara status pekerjaan ibu dengan status gizi serta penelitian yang menunjukkan tidak ditemukan adanya hubungan antarapekerjaan ibu dengan kejadian obesitas (Daryono, 2003) (Nugroho, 1999).

Berbeda dengan hasil penelitian yang menyatakan bahwa ditemukan hubungan antara pekerjaan ibu dengan kejadian obesitas (Meilinasari, 2002). Hal yang sama juga diungkapkan oleh Abdiana yang menyatakan bahwa ibu yang bekerja memiliki resiko 1,3 kali terjadinya kegemukan pada anak (Abdiana, 2010). Hal tersebut dikarenakan minimnya waktuyang dimiliki oleh ibu yang bekerja untuk menyiapkan, mengolah dan meyajikanmasakan yang bergizi. Frekuensi makan di luar rumah seperti makanan siap saji cenderung meningkat karena waktu yang tersedia untuk menyiapkan makanan di rumah sedikit (Lucas \& Ogata, 2005).

Keluarga dengan banyak anak dan kelahiran dekat akan menimbulkan banyak masalah. Seharusnya, dengan lebih banyaknya anggota keluarga akan memperkecil kemungkinan seseorang menjadi gemuk. Hal ini terjadi karena terlalu banyaknya jumlah angota keluarga selain menyulitkan dalam mengurusnya, juga bisa menciptakan suasana tidak tenang dirumah, khususnya bagi keluarga yang berpenghasilan rendah.

Berdasarkan tabel hasil analisis hubungan antara jumlah anggota keluarga dengan kegemukan pada anak balita diperoleh proporsi kejadian kegemukan pada anak balita dengan jumlah anggota keluarga $\leq 4$ orang sebesar $22,5 \%$, sedangkan untuk anak balita dengan anggota keluarga $>4$ orang yang mengalami kegemukan sebesar 8,7\%.

Hasil uji statistik dapat disimpulkan bahwa tidak adanya hubungan yang signifikan antara jumlah anggota keluarga dengan kegemukan pada anak balita. Hasil penelitian menunjukkan bahwa pada anak gemuk maupun tidak, proporsi jumlah anggota keluarga kecil maupun besar adalah tidak jauh berbeda. Hal ini sejalan dengan penelitian Musadat (2010), Adiningrum (2008), yang menunjukkan tidak ada hubungan yang nyata antara jumlah anggota keluarga dengan kejadian kegemukan (Adiningrum, 2008) (Musadat, 2010).

Jumlah anggota keluarga tidak mempengaruhi kegemukan pada anak. Pada jumlah anggota kecil dapat memberikan makanan yang maksimal dan optimal untuk kesehatan anak. Pada keluarga dengan jumlah anggota besar tentunya akan berpengaruh pada susunan menu makanan di rumah sehingga anak mengkonsumsi makanan yang lebih terbatas. Namun demikian, anak dapat menambah asupan gizi dari makanan cemilan yang disukai oleh anak.

\section{Simpulan}

Pada penelitian ini, sebagian besar responden memiliki badan yang tidak gemuk, berjenis kelamin laki-laki, berat badan lahir tidak berisiko, ibu dengan pendidikan tinggi (> SMA), ibu yang tidak bekerja, dan tinggal dalam keluarga besar ( $\geq 4$ orang). Ada hubungan antara jenis kelamin, berat badan lahir, pekerjaan ibu dengan kegemukan pada anak. Tidak ada hubungan antara pendidikan ibu dan jumlah keluarga dengan kegemukan pada anak.

\section{Referensi}

Abdiana. (2010). Hubungan Durasi Pemberian ASI dengan Kejadian Kegemukan pada Anak Taman KanakKanak di Wilayah Kerja Puskesmas 
Faletehan Health Journal, 6 (1) (2019) 1-10 www. journal.Ippm-stikesfa.ac.id/ojs/index.php/FHI ISSN 2088-673X | 2597-8667

Lubuk Buaya Kota Padang tahun 2010. Padang.

Adiningrum, R. (2008). Karakteristik Kegemukan pada Anak Sekolah dan remaja di Medan dan Jakarta Selatan. Bogor: Program Studi Gizi Masyarakat dan Sumberdaya Keluarga IPB.

Al-Qaoud, \& Prakash, P. (2009). Breastfeeding and Overweight among preschool Children. European Journal of Clinical Nutrition(63), 1041-1043.

Anderson, B. (2002). Imagined communities (Komunitas-komunitas Terbayang). (2 ed.). Yogyakarta: INSIST Bekerjasama dengan Pustaka Pelajar.

Cinta, R. N. (2009). Aktifitas Fisik, Konsumsi Makanan Cepat Sajic(Fastfood), dan Keterpaparan Media Serta Faktor-Faktor Lain yang Berhubungan dengan Kejadian Obesitas Pada Siswa SD Islam Al-Azhar Jakarta Selatan Tahun 2009. Depok: FKM UI.

Daryono. (2003). Hubungan antara konsumsi makanan, kebiasaan makan dan faktorfaktor lain dengan status gizi anak usia sekolah di SD Islam Al-Falah Jambi Tahun 2003. Depok: FKM UI.

Dupuy, M., Vignes, C., Godeau, E., \& Ahluwalia, N. (2011). Socio-demographic and lifestyle factors associated with overweight in a representative sample of 11-15 year olds in France: Results from the WHO-Collaborative Health Behaviour in School-aged Children (HBSC) cross-sectional study. BMC Public Health, 435:442.

Fitriarni. (2012). Hubungan Konsumsi Asi Eksklusif dan Faktor Lainnya Dengan Kejadian Kegemukan Pada Anak Usia 623 Bulan di Indonesia Tahun 2010 (Analisis Data RISKESDAS 2010). Depok: Fakultas Kesehatan Masyarakat UI.

Hariadi, \& Ali, A. (2005). Hubungan obesitas dengan beberapa faktor risiko penyakit jantung koroner di laboratorium klinik Prodia Makassar tahun 2005. Makassar: Prodia.
Kemenkes. (2010). Hasil Riset Kesehatan Dasar 2010. Jakarta: Badan Penelitian dan Pengembangan Kesehatan Kementerian Kesehatan RI.

Kemenkes. (2010). Kepmenkes No. 1995/Menkes/SK/XII/2010 tentang Standar Atropometri Status Gizi Anak. Jakarta: Kemenkes RI.

Kemenkes. (2012). Kebijakan dan Strategi Penanggulangan dan Pencegahan Kegemukan dan Obesitas di Indonesia. Jakarta: Direktorat Jenderal Bina Gizi dan Kesehatan Ibu dan Anak Kemenkes RI.

Kemenkes. (2013). Hasil Riset Kesehatan Dasar (RISKESDAS 2013). Jakarta: Badan Penelitian dan Kengembangan Kesehatan Kemenkes RI.

Kusumaningrum, F. (2011). Faktor-Faktor yang Berhubungan dengan Kegemukan pada Anak Usia 24-59 Bulan di Indonesia tahun 2010 (Analisis Data Riskesdas 2010). Depok: FKM UI.

Lopez, A. D., Mathers, C. D., Ezzati, M., Jamison, D. T., \& Murray, C. J. (2006). Global and regional burden of disease and risk factors, 2001:systematic analysis of population health data. Washington (DC): The International Bank for Reconstruction and Development / The World Bank; New York: Oxford University Press.

Lucas, B., \& Ogata, B. (2005). Normal Nutrition From Infancy Through Adolescence. In P. Samour, \& K. E. King, Handbook Of Pedriatic Nutrition (p. 107). Sudbury MA: Jones and Bartlett Publishers Inc.

Meilinasari. (2002). Hubungan Gizi Lebih Dengan Asupan Energy Pada Anak SD Al-Azhar 6 Permai Bekasi. Depok: FKM UI.

Musadat, A. (2010). Analisis Faktor-Faktor Yang MempengaruhiKegemukan Pada Anak Usia 6-14 Tahun di Provinsi Sumatera Selatan. Bogor: Sekolah Pasca Sarjana IPB. 
Notoatmodjo, S. (2005). Metodologi penelitian kesehatan. Jakarta: Rineka Cipta.

Nugroho. (1999). Studi beberapa karakteristik yang berhubungan dengan status gizi anak kelas IV dan V dari kelompok social ekonomi menengah keatas di SD Hj. Isriati Kodya Semarang. Depok: FKM UI.

Rahmawati, N. (2009). Aktifitas Fisik, Konsumsi Makanan Cepat Saji Fastfood), dan Keterpaparan Media Serta FaktorFaktor Lain yang Berhubungandengan Kejadian Obesitas Pada Siswa SD Islam Al-Azhar Jakarta Selatan Tahun 2009. Depok: FKM UI.

Rimbawan, S. (2004). Indeks Glikemik Pangan. Jakarta: Penebar Swadaya.

Suhardjo. (2003). Berbagai Cara Pendidikan Gizi. Jakarta: Bumi Aksara. 